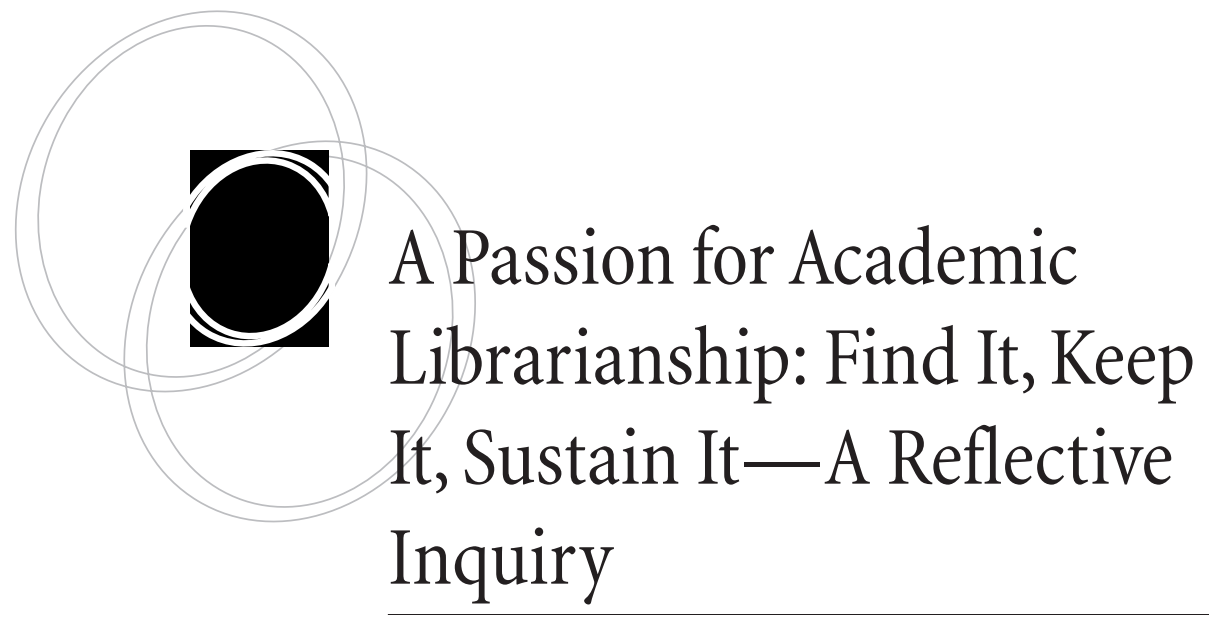

Steven J. Bell

abstract: Why do academic librarians do what they do? This article explores the sources of passion that make academic librarianship a rewarding profession. A framework is introduced that examines the relationships within and outside the academy that contribute to the academic librarian's professional passion. The challenge of sustaining professional passion is addressed.

There's lots of passion in the library. Depending on one's library setting, references to passion may bring to mind images of romance novels or PDAs among the book stacks (that's "public displays of affection" not handheld devices). This article examines another type of passion, the professional kind. Every academic librarian should acknowledge his or her professional passion, and channel it into energy and enthusiasm for the people and things we need to pay constant attention to if our organizations and we are to excel. Put simply, passion is not a commodity that you produce. Passion is a byproduct of doing something you really enjoy.

It would be ludicrous to suggest that every academic librarian is passionate about his or her profession. Everyone has known a colleague who was pretty miserable coming to work. Why did that person chose this profession, and was he or she was ever passionate about librarianship? For some it's just burnout. Perhaps it was an incompetent manager or the inability or lack of willingness to keep up with professional change. For a few others, it might be the low salary, but the profession has its share of well-paid malcontents. What matters is whether you enjoy your job so that is creates personal passion. But if those other librarians lost their passion, why doesn't it happen to all of us eventually?

portal: Libraries and the Academy, Vol. 3, No. 4 (2003), pp. 633-642. Copyright (c) 2003 by The Johns Hopkins University Press, Baltimore, MD 21218. 
Professional and romantic passions have at least one thing in common. If you take either one for granted long enough it will eventually desert you. We rarely think about our professional passion. What are its sources, what keeps it alive, and how do we sustain it? This article is designed to provide an opportunity to contemplate our passion for academic librarianship so that it may be better appreciated. But passion is a nebulous topic. In an effort to better understand it, this article presents a framework referred to as Four Frames of Passion. The frames are grounded in those relationships we have with the members of our academic community. They span from our local, immediate workplace to the global and virtual networks in which we operate.

A core premise of the framework is that these relationships and how we embrace them form the foundation of professional passion. The diagram illustrates the four frames.

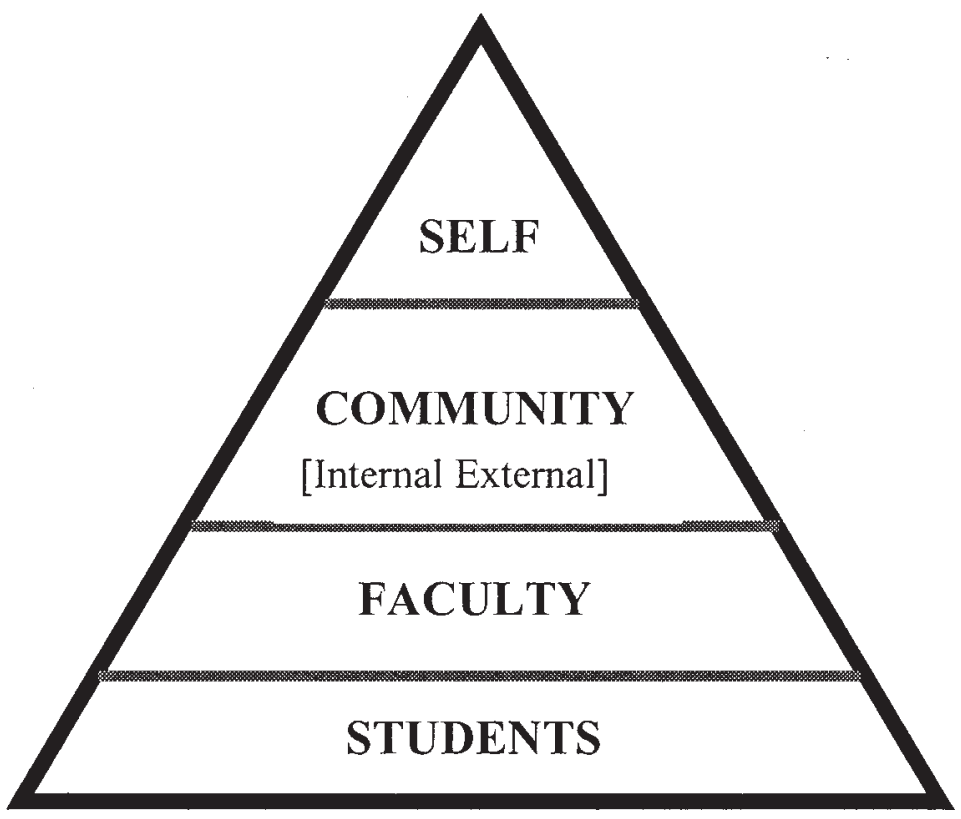

The diagram might suggest that like Maslow's Hierarchy of Needs it is necessary that the lower frames be solidly in place before the upper ones can be achieved. In this hierarchy the frames are interconnected, and imply that the achievement of professional passion is dependent on fostering a range of relationships that jointly contribute to individual professional passion. This framework provides a conceptual lens with which to magnify and dissect passion in order to identify the parameters of our passion. Put another way, this article's goal is to help each academic librarian gain a unique perspective on "why we do it" so that he or she may avoid falling victim to lack of passion.

\section{Moments of Passion}

I received a puzzling e-mail during the spring 2002 semester. A Swedish librarian, Daniel Gunnarson, had a request. He was leading colleagues on a tour of east coast academic 
libraries that summer and wished to make arrangements to visit my library. Philadelphia University is a relatively small institution, and the library assets reflect that status. Something was not right here. Despite the e-mail's unmistakable description of our library's website, services, and resources, it was of a dubious nature. If we were coming from Europe to visit a few select academic libraries, my librarians acknowledged that ours would not be among them. A reply to Mr. Gunnarson, to ascertain the facts, inquired as to the other libraries on the tour itinerary. As we suspected, his response contained a "who's who" of prominent academic libraries. In time, we unraveled the confusion. Daniel had confused our library with that of a well-known Ivy League institution in the same city (how well can you differentiate Swedish universities by their geographically-linked names?).

Despite an invitation to stop by when his group was in town, there were no Swedish librarian sightings that summer. But as I thought back to the moment I read his apologetic response and the smile it brought to my face, I realized he had thought our library to be among some select group based solely on his exploration of our website. In that moment I realized the hard work we put into our website, our effort to acquire the right resources and make them accessible, and the difficult choices we make about addedvalue services to bring to our community were all worth it. What happened in that space of just a few seconds and some cognitive awareness can be described as a "moment of passion."

In other words, "why we did it" was to enjoy a moment of supreme satisfaction and self-reward such as this. Academic librarians seem to have more than their share of such moments:

- We help patrons frustrated with complex research projects unravel the mysteries of the process so that they "get it."

- We hear from alumni who let us know how we've contributed to their success.

- We find answers to elusive, challenging questions that befuddle mere mortals.

We need these moments of passion, and we must endeavor to help our staff and colleagues experience them. And we need to remember them and savor them on those days when we wonder why we're doing this. And while these moments, like the one I described above, last but a few glorious seconds, others may have deep and long-term impacts. Moments of passion can also anger and motivate us to ask questions, to explore what we need to understand, or to pursue what were once only dreams. I believe those moments contribute to our profession's finest accom-

We need these moments of passion, and we must endeavor to help our staff and colleagues experience them.

plishments, its outstanding scholarly articles, its harnessing technology to develop exciting new services, its revolutionary discussion lists, e-zines, and blogs, and all those things that turn ordinary librarians into innovators and leaders. 


\section{The Student Frame}

Students represent a logical starting point. The fundamental library user must be the foundation of the framework's pyramid because they are essential to why we are doing what we do. They are why we are here. Students give us our most direct opportunity to be a part of the teaching and learning process at our institutions. The information literacy movement is a tremendous boon to librarians whose passion focuses on students for it creates more opportunities for direct interaction with students. In a way the traditional bibliographic instruction never did, information literacy initiatives serve to legitimize academic librarian participation in the teaching and learning process, and validate for faculty our contributions to student learning.

Our passion for students and their need to develop sound information seeking skills is starting to gain attention in larger arenas. Consider that 2002 provided record numbers of mainstream newspaper articles about the challenges of Internet searching, the role librarians are playing in educating the masses about effective search skills, and how, in general, librarians evolved into techno-savvy masters of the Internet universe. Two Pew Internet \& American Life Studies, an OCLC White Paper, and a joint Digital Library Federation and Council on Library and Information Resources (CLIR) study confirmed what we knew all along about how students' web-centricity and dependence on Internet sites for research and writing contribute to declining research skills. ${ }^{1}$ These accumulated reports affirm that our passion for students is well placed and deserving of recognition.

Lest the focus on information literacy issues give the misguid impression that passion for interaction with students is the sole domain of the instruction librarian, colleagues in interlibrary loan, circulation, reserve, and technical services

Interaction with students of any age is a primary benefit of the education environment for it keeps us in a youthful state of mind where we can constantly learn and prosper from intellectual challenges. can connect with students as well. Outreach opportunities abound for involvement with students outside the library, ranging from providing information services in cafeterias and dormitories to participating in campus community activities. Interaction with students of any age is a primary benefit of the education environment for it keeps us in a youthful state of mind where we can constantly learn and prosper from intellectual challenges.

\section{The Faculty Frame}

If connecting to the teaching and learning process is a source of professional passion, faculty collaboration makes it happen. At some institutions, faculty-librarian relationships may be a source of professional frustration. Faculty may be unreceptive to gestures for collaboration. But passionate academic librarians achieve success with two important qualities: risk taking and persistence. A personal vision shaped by these two 
is a third ingredient for success. My own is that I firmly believe the future of academic librarianship will depend on our ability to integrate or blend into the teaching and learning process in ways that far surpass current bibliographic instruction practices. Several trends are converging to create a new role we'll play in the academic enterprise.

Course Management Software (CMS) such as Blackboard CourseInfo or Web-CT is becoming ubiquitous in higher education. Librarians must seek out ways to establish their presence within the CMS as a means of further integrating into the faculty's domain. The goal is to create new opportunities to disseminate information about the library and provide access to resources to students in an environment strongly associated with teaching and learning. A number of approaches are being demonstrated, from library tutorials and full-scale instruction classes on the CMS to unique links to library resources placed within course pages. CMS enhances our ability to migrate what we do in the library to the classroom, even in the virtual classroom.

A less familiar trend is the Low Threshold Application (LTA). Steve Gilbert, President of the TLT Group, developed and champions the LTA concept. It promotes the practice of introducing faculty to simple, easy to learn, no or low cost, and easy to apply technologies for teaching and learning. Most faculty shun technologies that require too much time or effort to learn. A good LTA is any small technology application that faculty can quickly master and start using immediately; discover good examples at http:/ /www.tltgroup.org/LTAs/Overview.htm. LTAs are a natural for librarians. We have an abundance of technologies for which there is no direct cost for faculty, they're fairly easy to learn, and many can be readily applied to classroom activities. Not only do LTAs offer another avenue for connecting with faculty, but they also enhance our campus reputation as technology experts. I spend a fair amount of time searching for and experimenting with new technologies because I am passionate about the role it can play in shaping our future in higher education.

Librarians will need more than technology savvy to achieve true integration into the teaching and learning process. Our colleagues in information technology and instructional technology are endowed with technology skills as well. How do we differentiate ourselves in this arena? We can pursue a new role, one I refer to as the "Blended Librarian." The Blended Librarian first combines the traditional aspects of librarianship with the technology skills of an information technologist, someone skilled with software and hardware. Many librarians already demonstrate sound technology skills of this type. To this mix the Blended Librarian adds the instructional or educational technologist's skills for curriculum design, and the application of technology for student-centered learning. Few librarians have instructional technology skills. Library science curricula need re-structuring that adds some pedagogical foundation to the academic librarian's professional education. The Blended Librarian is the academic professional who offers the best combination of skills and services to help faculty apply technology for enhanced teaching and learning.

\section{The Community Frame}

When I worked at a large research university a few years back it was difficult to know everyone in the library let alone everyone in an organization with thousands of em- 
ployees. In the smaller academic community in which I now work I know a much higher percentage of the overall workforce, and at least one person from every office on campus. I would encourage librarians in organizations of all sizes to know and interact with as many people as possible in their internal academic community, and with professional colleagues outside their institution as it will add significantly to professional passion. As a part of a larger community, the sense of contributing to the overall goals of the organization or association is enhanced.

This frame's message is a familiar one: the more you put into it the more you get out of it. Community involvement is the seedbed of professional passion for many librarians, and it functions on two levels, the internal and external. Internal relates to your organization and co-workers, while external relates to your academic library colleagues outside the organization. Here's a simple example of the benefits of being active in your internal community. My staff and I wanted to experiment with delivering library services to students in the residence halls. Other libraries had reported successful outreach ventures of this type. Getting started required logistical preparations beyond our capacity. My university's Residence Life director and I had gotten to know each other only because on occasion we happened to use the fitness room together. Through this relationship I discovered the director was open to the idea, and he assisted us with the arrangements every step of the way. The outreach effort less than satisfactory, but the library staff realized that connections with administrative colleagues are as powerful a tool in achieving our library objectives as is faculty collaboration.

Any community, and par-

\section{Partnering with fellow academic administrators enables us to accomplish more through a united front than by seeking change individually.}

ticularly an academic one, benefits from strength in numbers. Partnering with fellow academic administrators enables us to accomplish more through a united front than by seeking change individually. Your goals will sometimes differ and may even conflict, but it will almost always be advantageous to have allies in your community. Here are suggestions for getting more involved in your campus community and increasing interactions with administrators in other offices.

- Get involved in non-library committees; I've served on two different ones during our institution's migration to a new campus automation system. Though the library will gain few benefits from this system, I've made many contacts and learned a tremendous amount about admissions, financial aid and registrar functions.

- Meet your fellow administrators for lunch or recreational activities, on or off campus; every campus offers a book club, an aerobics class, a fitness center, and other types of opportunities to create connections.

- Participate in campus activities, such as open houses, planning campus information fairs, campus clean-up events, or helping to organize student social programs; all require interaction with Student Life officers. 
- Invite other administrators to get involved in your library programs when appropriate. Writing Program Directors and Learning Center colleagues make strong allies for your information literacy initiative, and other program ventures.

Every academic librarian is also part of the larger, external community of information professionals that operates on the local, regional, national, and virtual levels. Opportunities for involvement are possible at every level. At any level, working with a colleague to develop an article for publication or a presentation is a source of enjoyment that is sure to produce passion. Those less motivated to present or publish can be active in the larger library community through professional association participation. We all have a colleague who is perennially active as an association officer or committee member. These folks derive passion from their involvement in organizations, and those I know are passionate in their belief that this is how they make a difference in our profession.

Getting involved in professional organizations may be time consuming and it will almost always call for hard work, but the satisfaction derived from working with colleagues to put together a well-received program is among the finest feelings obtainable in a career. You may encounter your share of dull meetings, plans that come to naught, and programs that you'll wished you'd never been involved in, but I would guarantee that the good collegial experiences will far outweigh the bad ones. Whether your community involvement is internal or external, aim to be more involved and less detached. It is always easier to be passionate about an organization or association when one has social, cultural, and emotional connections to an organization's outcomes and achievements.

\section{The Self Frame}

The fourth frame is all about you. Developing that passionate "I-can't-wait-to-get-towork" feeling will ultimately depend on your ability to build a foundation from the other three frames. It's a holistic approach. Interaction with students, faculty, your community and colleagues leads to self-awareness about what form one's own personal, professional development should take. Academic librarians with a well-rounded professional life almost effortlessly develop the passion that takes their abilities to that next level.

Start by pursuing a passion for staying on top of your game. Like athletes who maintain regimens for staying in top condition, each of us must develop a regimen for personal, professional development. Many of us already follow the basic library journals, attend conferences and other library-oriented continuing education programs, and are members of relevant discussion lists. Those approaches are certainly useful to stay alert to recent developments in the library field. But innovation rarely happens by limiting one's self to a familiar field of play. Take a closer look at the individuals profiled in Library Journal's Movers \& Shakers issues (3/15/02 and 3/15/03) and a common theme emerges. These individuals challenge the status quo. In doing so they redefine our profession, and establish new levels of achievement in personal, professional development.

Technology is advancing so rapidly that librarians need to be well versed in many different technology areas peripheral to our own field. Staying on top of your game requires getting beyond developments in librarianship. One of my passions is serving 
as a proponent of "keeping up," and I have two basic philosophies for tackling this time-consuming activity. It can be best managed with a variety of electronic resources, and is most effective when it encompasses resources beyond the boundaries of librarianship. My Keeping Up website is designed to help all librarians develop a personal, electronic-based regimen for keeping up with librarianship and the peripheral technology fields with which it is associated. ${ }^{2}$ Visitors to the site can avail themselves of more than eighty free e-newsletters, e-zines, Web sites and other sources that can weave an effective strategy for keeping up, discovering new ideas, and stimulating innovation and stirring passion in any librarian.

From my perspective, keeping up leads to innovation and innovation leads to the desire to express one's self through professional literature or conference contributions. Finding ideas for and time to develop articles or presentations is a significant professional challenge. Keeping up is closely connected with researching and writing. The former can fuel the innovative ideas needed for the latter. I enjoy experimenting with new technologies, most often web-based utilities, and often do so in hope of discovering a resource that will improve personal productivity, library services, or instruction skills. Almost two years ago I discovered webcasting, a technology that broadcasts lectures, presentations, and interactive seminars across the Internet. Eventually, I began to experiment with webcasts as a teaching tool, using them in my own classes. I eventually gained enough experience to publish an article on the topic. Had I not first discovered the webcast concept in a non-library technology newsletter to which I subscribe, the article would never have materialized.

\section{Sustaining the Passion}

Good literature on finding and sustaining professional passion is in short supply, and what lessons might be learned from it boils down to two types of information; the warnings signs of passionlessness and strategies for finding or renewing personal passion. Typical warning signs include those feelings that lead to professional unhappiness. You feel trapped, bored, or completely stressed. You feel your job no longer challenges you or expands your skill set. You feel you are not who you should be, or are not living up to your potential. Awareness of diminished or lost passion may be brought on by a "wake-up" call, some major life or societal event that triggers questions about personal and professional commitments and their meaning.

The literature offers value by providing advice for re-discovering and sustaining professional passion. If possible, take some time out from your daily routine. Few of us can take a re-invigorating sabbatical, but even a few days off to contemplate one's personal mission can help plan a new path for professional renewal and development. Investigate one of the many professional development programs the library profession offers. Programs such as the Association of College and Research Libraries' Leadership Institute are proven strategies for stirring professional passion. Among the simplest of the recommended strategies is carving out "reflective time." No matter what is happening in my professional life, despite an overwhelming schedule or deadline pressures, I find that starting each day with one hour of keeping up activities reduces stress and reminds me why I'm doing it all. Others may find mentoring or coaching programs of help. 
Personally, I'm an advocate of professional risk taking. I realize that risk taking can cause professional discomfort for many librarians. But there are clear connections between passionate professionals and their risk-taking behavior. The business literature is replete with tales of successful leaders and the risks they took. Certainly, many of these individuals' risks resulted in failures, but all would agree that it was professionally satisfying to take the risk rather than take no chances at all. Failure is scary, but the profiles of risk-taking leaders assure us that we will all have our failures and that no gain can be achieved without some risk. Consider that every risk is essentially an investment of time and resources with no guarantee of return. If you are risk adverse consider that the simple act of reading this article was a risk because you invested your most precious resource, time, with no certainty of return. Start with this small concept and develop it into a better mental outlook about risk taking and challenging the status quo in your library.

\section{Conclusion}

When all is said and done all that will really matter is whether or not you, as an individual academic librarian, as a colleague to others, and as a member of a professional community, were able to make a difference in the lives of those you chose to serve. I truly believe the majority of librarians do make a difference on a daily basis. But to avoid what I call "drift," plateauing in our careers and in our libraries, it's going to take a real passion for the profession to keep us driving ourselves to do more, to do it better, and to do it in a way that gains recognition for ourselves and our profession.

You may recall a minor controversy during the 2002 election season, as a candidate for the New Jersey Senate seat, Doug Forrester, referred to himself as a librarian in a campaign commercial. The New Jersey Library Association discovered and made public that Forrester merely worked briefly as a stack attendant at his college library, and therefore had no right to refer to himself as a librarian. Our image conscious profession had a predictable reaction that set the pro-MLS and no-MLS camps against each other on various discussion lists. The latter saw no harm in what Forrester had done since, in their opinion, the MLS is just a manufactured credential, that it isn't needed to be a librarian, and that a bachelor's degree and some practical training at a reference desk is all one needs.

I was surprised to learn that some of the non-MLS crowd admitted they were degreed librarians, and that the only reason they obtained the degree was for the credential. I questioned if these folks had any real passion for the profession and how they justify why they do what they do. As Richard Chang, author of The Passion Plan says, "If you don't have a passion for the business you are in, you don't belong in it." 3 Our profession is challenged on many fronts, everything from the myth of the deserted library to the library without books, to competition from the Internet and marketplace competitors, to salary and recruitment issues-the list is long. I have great confidence that academic librarians can meet these challenges and continue to create advances as we explore new roles for our libraries and ourselves. To my way of thinking, it is our passion for academic librarianship that will fuel the future of our profession. 
Steven J. Bell is Director of the Library at Philadelphia University; he may be contacted via email at: bells@philau.edu.

\section{Notes}

1. The Pew Internet \& American Life Project Report, "The Digital Disconnect: The Widening Gap Between Internet-Savvy Students and Schools" (August 14, 2002). Available: <http:/ / www.pewinternet.org/reports/toc.asp?Report=67> [September 14, 2003]; The Pew Internet \& American Life Project Report, "The Internet Goes to College: How Today's Students Are Living in the Future with Today's Technology" (September 15, 2002). Available: <http:/ /www.pewinternet.org/reports/toc.asp?Report=71> [September 14, 2003]; OCLC White Paper on the Information Habits of College Students, "How Academic Librarians Can Influence Students' Web-Based Information Choices" (June 2002).

Available: <http://www.oclc.org/services/brochures/informationhabits.pdf > [September 16, 2003]; Amy Friedlander, "Dimensions and Use of the Scholarly Information Environment" (November 2002), a pre-publication version of the DLF, CLIR and Outsell Inc. study, Voice of the User: Where Students and Faculty Go For Information. Available: <http:/ / www.clir.org/pubs/reports/pub110/contents.html> [September 14, 2003].

2. Steven Bell's Keeping Up Web Site is available at: <http://staff.philau.edu/bells/keepup> [September 14, 2003].

3. Richard Chang, The Passion Plan: A Step-By-Step Guide to Discovering, Developing and Living Your Passion (San Francisco: Jossey-Bass, 1999), 15. 